\title{
Said Nursi's Psycho-spiritual Therapy for Psychological Reactions of Patients with Physical Illnesses
}

\author{
MR Ahmad Nabil ${ }^{a}$, Tahir MFMa , Thomas $N S^{b}$, Gülerce $H^{c}$ \\ ${ }^{a}$ Department of Psychiatry, Kuliyyah of Medicine, International Islamic University Malaysia \\ ${ }^{b}$ Uskudar University, Altunizade, Haluk Turksoy, Sk. No: 14, 34662, Uskudar, Turkey \\ 'Department of Sociology, Harran University, Turkey
}

\section{INTRODUCTION}

\section{Psychological reactions among medically ill}

Depression and anxiety are relatively common psychological reactions among those with chronic physical illnesses. ${ }^{1}$ It has been associated with low quality of life and impairment of daily functions. ${ }^{1}$ Cognitive behavioral therapy has been shown to be effective in helping patients to deal with maladaptive beliefs about their illnesses that predispose and perpetuate the psychological reactions. $^{2}$ An event e.g. illness, may be interpreted differently by different individuals from a cognitive point of view. ${ }^{2}$ A person who attaches an unrealistic extravagant meaning to it, will result in an excessive emotional reaction. The cognitive content of a depressed patient centers on significant loss e.g. health, while an anxious patient harbors thoughts of imminent danger e.g. fear of loss. $^{2}$

\section{Cognitive therapy and Islam}

Cognitive restructuring as its name indicates, is a form of cognitive therapy which identifies unhelpful thoughts and substitutes them with alternative thoughts. ${ }^{3}$ However, the conventional cognitive therapy has its limitations where its philosophical underpinnings denies the existence of absolute reality as proposed by the Quran. ${ }^{4}$ Alternatively, psychotherapy that integrates patients' religious beliefs and spirituality in its therapy, may help to relieve depression and anxiety, especially among religious patients. ${ }^{5}$ However, many of the research

Corresponding Author:

Asst. Prof. Dr. Ahmad Nabil bin Md. Rosli

Department of Psychiatry,

Kulliyyah of Medicine,

International Islamic University Malaysia,

25200 Kuantan, Pahang, Malaysia.

Tel No: +609-5706211

Email: ahmadnabil@iium.edu.my efforts on Islam and psychotherapy have only adopted Western theories and models, without designing one with a fresh and unique outlook of Islamic origin. ${ }^{6}$ In order to address the unmet needs of the Muslim clients with mental health issues such as depression and anxiety, a spiritually-based Islamic therapy can be offered to the Muslim clients. This may bridge the gap between people and the service provider and empower Muslim clients to utilize such services. $^{7}$

\section{Said Nursi and Risale-i Nur}

Bediuzzaman Said Nursi (1877-1960) was a prominent Muslim thinker, known for his active work in theology and Quranic commentary. He penned voluminous writings on Quranic commentary which is also known as Risale-i Nur. ${ }^{8}$ As he is considered as one of the Muslim revivalists (mujaddid), there is a need to study his thoughts and works, especially in relation to mental health and psychotherapy among patients with physical illnesses. There are some studies on Islamic concepts of religious obsessivecompulsive disorder in Risale-i Nur which are discussed in the light of modern psychiatric perspective. ${ }^{9}$ There is also a study that explains the integrated concept of Muslim prayer, positive religious coping and attachment from the Risale- $i$ Nur and modern psychology perspectives. ${ }^{10}$ However, published research works on mental health based on the Risale-i Nur's perspective are rather scarce. ${ }^{11}$

\section{Psycho-spiritual Well-being}

The World Health Organization (WHO) has defined health as a state of complete physical, mental and social well-being and not merely the absence of disease or infirmity. ${ }^{12}$ However, others have criticized this definition highlighting its static nature i.e. 'state of complete' and medicalization of society as the reasons. ${ }^{13}$ Instead, a new dynamic formulation of health i.e. ability to adapt and to 
self-manage in the face of social, physical and emotional challenges, focuses on resilience and ability to cope with adversity. ${ }^{13}$ This latter definition is more rational, if health is to be viewed from the Islamic perspective.

A framework on Said Nursi's perspective of psychological well-being was proposed from the Risale-i Nur which is based on the Quranic spiritual dimension by inserting Seligman's positive psychology. ${ }^{11}$ Hope, courage, truthfulness, love, solidarity and sincerity are the universal core values in the psycho-spiritual well-being dimension. The four guiding principles of the method of Risale-i Nur based on the Quran as the source of belief which are: acknowledging weaknesses, awareness of neediness, absorbing compassion and applying reflective thoughts eventually guides one to attain the psycho-spiritual well-being. Hope and courage are thought to be of relevance to the problem of hopelessness in depression and fear in anxiety. Thus, this study aims to explain the Risale-i Nur's approach in handling depressed and anxious emotions and attempts to briefly discuss the therapeutic components of the treatise, which can be potentially utilized and integrated into therapy.

\section{Said Nursi's 'Message for the Sick'}

\section{The concept of health and illness}

Said Nursi conveys a message specifically for the sick in The Twenty Fifth Flashes of his Risale-i Nur collection where he prescribes twenty five spiritual remedies. He presents in an entirely different perspective on the notion of illness which is viewed in the light of Quran through the lens of a believer. Thus, illness is seen to contain many benefits, advantages and instances of wisdom; it is not something to be feared but as something that brings goodness. Said Nursi conceptualizes the notions of health and illness rooted in Islamic tradition as "Illness is good health"14 - only if it is perceived from the right worldview, which enables one to cope with illness healthily.

Illness is of two types; real and imagination and the former refers to any illnesses with tangible evidence while the latter - also known as hypochondria - is a mental disorder where a patient worries excessively until he becomes preoccupied with non-existing bodily symptoms. Said Nursi urges that a real illness must be treated according to the advice of an authorized physician, but hypochondriasis is best treated by ignoring the worry. Regardless of the typology, an illness serves certain purposes. Metaphorically, he likens an illness to that of a capital; ${ }^{15}$

"Illness makes that capital of yours yield huge profits. Moreover, it does not allow your life to pass quickly, it restrains it and lengthens it, so that it will depart after yielding its fruits. An indication that your life is lengthened through illness is the following much repeated proverb: "The times of calamity are long, the times of happiness, most brief." (p. 266)

\section{Psychological response to illness}

The common emotions experienced by the sick are correctly identified by Said Nursi. He opines that sadness, fear and anticipatory anxiety develop due to the fact that illness may lead to separation and death. A man who attaches negative meanings to illness would result in having negative emotions. The preoccupation with worry would exacerbate his physical condition. Said Nursi's views are in conformity with the modern psychosomatic medicine in explaining the relationship between worry and physical illness when he writes; ${ }^{16}$

"In fact, worry doubles the illness, for it causes an immaterial illness of the heart underlying the physical illness; the physical illness subsists through that and persists...Sometimes a minor physical illness increases tenfold just through anxiety. If the anxiety ceases, nine tenths of the illness disappears." (p. 272)

A person is said to be in the state of heedlessness (al-ghaflah) if he is unaware of the true purpose of his existence. Over attachment or infinite love of one's existence in this life is identified as the root cause of distorted thinking (cognitive distortion in modern psychology) which eventually produces negative emotions in the face of illness. One has a boundless capacity to love everything that exists. His lower self (nafs al-amara) subtly instills the notion of self-sufficient where one holds an odd belief that he is immortal. This belief is then being continuously reinforced by the state of being well and healthy. Thus, an illness serves as a spiritual 
awakening to remind man of his real purpose and the meaning of his life.

Figure 1 displays the origin of illness i.e. despair and fear, in the context of physical illness which is based on the Risale $i$ Nur's perspective.
These themes are considered as 'positive actions' which can be used to attain psycho-spiritual wellbeing which focuses on hope and courage as remedies for depression and anxiety. Said Nursi strongly practices 'positive action' as a principle even in hopeless situations and within absolute despair and desolation. ${ }^{17}$ It has become his lifelong principle which is based on knowledge, learning,

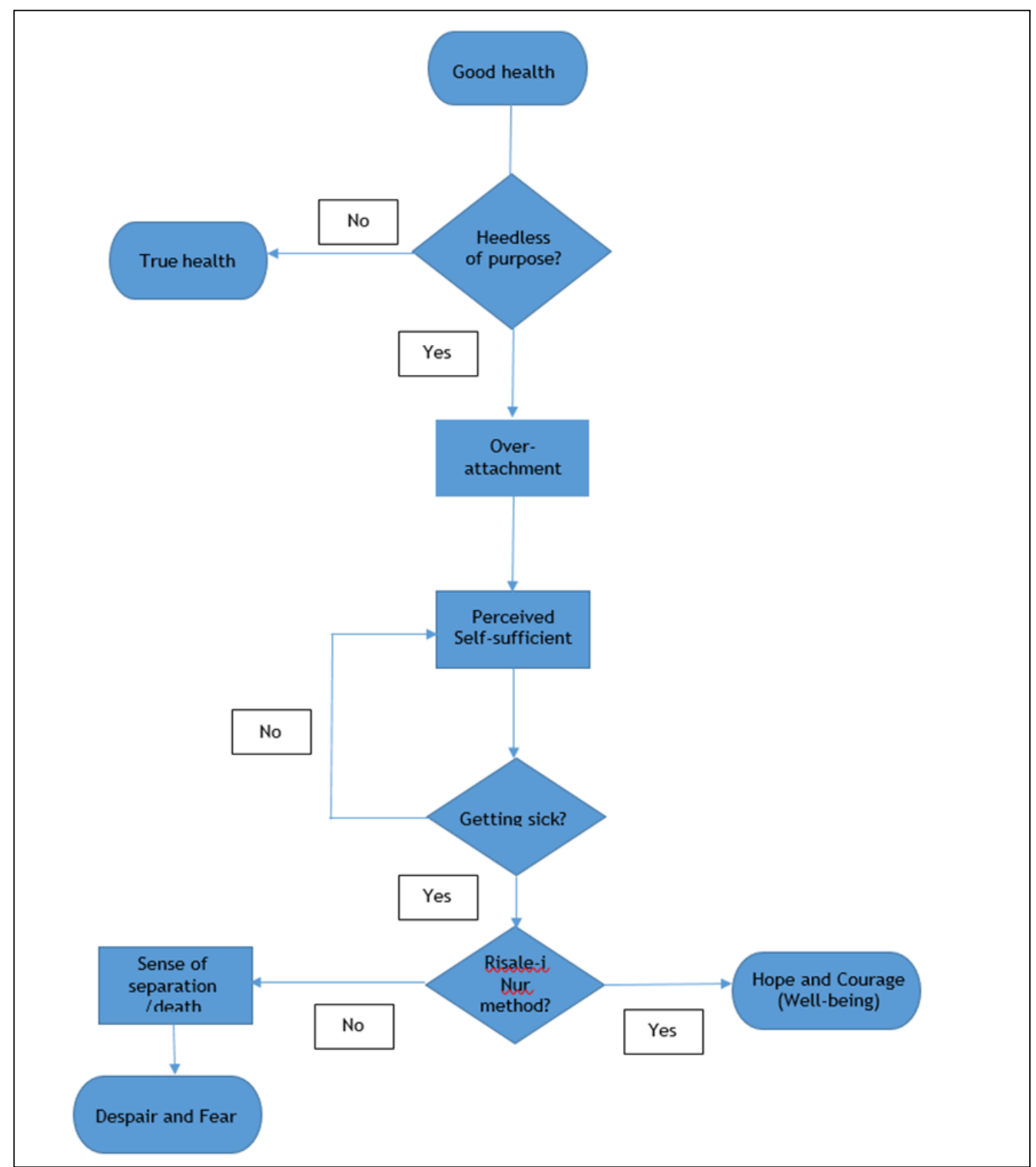

Figure 1: The origin of illness i.e. despair and fear, in the context of physical illness which is based on the Risale- $i$ Nur's perspective

\section{Treatments}

Said Nursi prescribes remedies as treatments for physical and psychological illnesses in his 'Message for the sick' and the intervention can be categorized into the following themes: i) acceptance (rida), ii) positive thoughts (husn dhann), iii) remembrance of God (dhikr), iv) patience (sabr), v) gratitude (shukr), vi) detachment (zuhd), vii) prayer/ Supplication (dua), viii) psycho-social support (takaful). persuasion, love, compassion and conveying the message of truth. ${ }^{18}$ Said Nursi's 'positive action' based on positive ideas and emotions refers to his method of patient and silent spiritual struggle to save and strengthen belief in God by peaceful means. ${ }^{19}$ Figure 2 displays a proposed framework for psycho-spiritual therapy to attain hope and courage based on the Risale i Nur's perspective. 


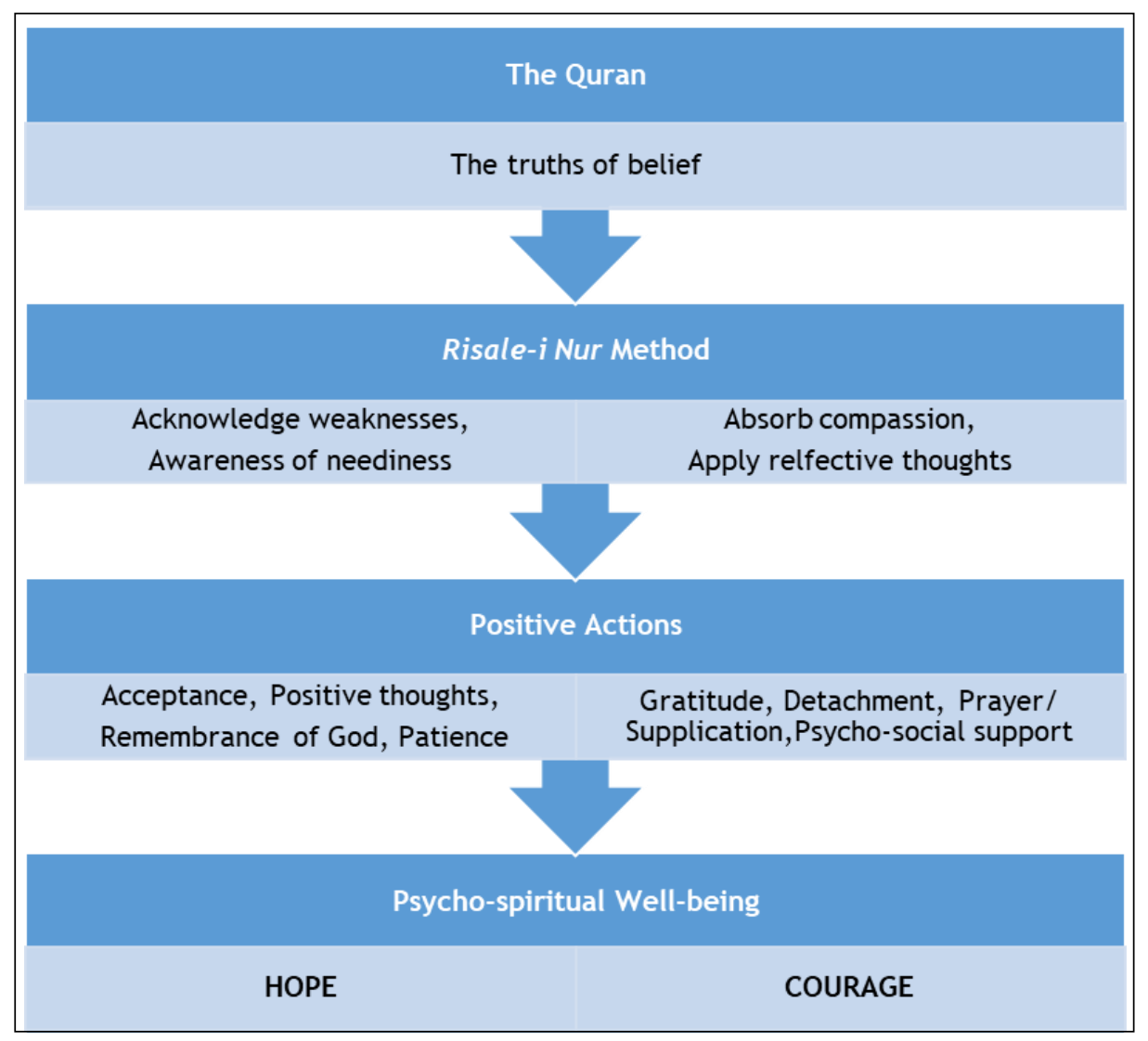

Figure 2: A proposed framework for psycho-spiritual therapy to attain hope and courage based on the Risale-i Nur's perspective

\section{Acceptance (rida)}

Literally, rida means to accept or to be content. ${ }^{20}$ Misfortune refers to anything that is distressful e.g. physical or emotional disturbances. It must be noted here that acceptance must be coupled with a correct comprehension of the nature of an event. Said Nursi comments on worry by asserting; ${ }^{16}$

"the worry ceases through submission, contentment, and comprehension of the reason for the illness, a large part of the illness is eradicated" ( $p .272)$

In another part of Risale-i Nur, Said Nursi indirectly indicates and illustrates the importance of acceptance in dealing with recurrent obsessive thoughts. He portrays it as; ${ }^{21}$

"A calamity! The more importance they are given, the more they grow. If you give them no importance, they die away. If you see them as big, they grow bigger... If you do not fear them, they are light and remain hidden. If you do not know their true nature, they persist and become established. While if you do know them and recognize them, they disappear" (p. 281)

\section{Positive thought (husn al-zann)}

The most recurring theme in Said Nursi's remedies against negative emotions is the role of inculcating positive meanings to one's experience. He advocates his readers to comprehend the reason for the illness. Guided by Islamic sources, Said Nursi advises patients to view their illness beyond what is apparent to them i.e mere pain. He states; ${ }^{14}$

"Do not look at the outward aspect of illness...consider its meaning and be pleased...there is a Hadith the meaning of which is, "Those afflicted with the severest trials are the prophets, then the saints and those like them." (p. 275)

The negative consequences of illness i.e. functional impairment can be seen as a form of continuous worship for the believers. As modern psychiatry testifies the known effect of delayed sense of time in depressed patients, Said Nursi frames a positive meaning to it as he asserts; ${ }^{14}$

"For life departs like capital...Illness makes that capital of yours yield huge profits. Moreover, it 
does not allow your life to pass quickly; it restrains it and lengthens it, so that it will depart after yielding its fruits." (p. 266)

\section{Remembrance of God (dhikr)}

Said Nursi is right about the nature of man's mind which is wandering and volatile, worries about the future and grieves his past. The heedlessness (al-ghaflah) exhausts man's mind from his real purpose of life and he becomes preoccupied of himself. Instead, remembrance (dhikr) removes the egocentric consciousness to other than himself i.e. Allah. Thus, he suggests that patients need to be in constant remembrance of God in the present moment and verbalize positive utterance as he asserts; ${ }^{14}$

"So to think of past days and feel grieved and impatient is crazy. Future days have not yet arrived...do not scatter the power of patience given you by Almighty God to right and left, but muster it in the face of pain of the present hour; say: "O Most Patient One!" and withstand it." ( $p$. 273)

Said Nursi states in The Fourth Rays of his Risale-i Nur that he recourse to the verse 'For God suffices' (Quran 3: 173) in times of grievous anxiety. He also finds solace through remembrance of God as he states in The Fifth Letter of his Risalei Nur. ${ }^{22}$

\section{Patience (sabr)}

Literally, sabr means to bind or to restrain, ${ }^{20}$ while technically it refers to restraining oneself from that which is harmful, and to endure what one dislikes with a sense of acceptance. ${ }^{23}$ It is a potential in oneself that develops from the right understanding on the purpose of illness and without it one will act impulsively; ${ }^{14}$

"You become impatient because you imagine things wrongly. For both the physical illness prior to today, and its pain, have departed; all that remains are its reward and the pleasure at its passing. This should afford you profit and happiness" (p. 272)

\section{Gratitude (shukr)}

Patients are encouraged to offer gratitude and thanks, focusing on what is present rather than what is absent. It can be facilitated by observing others who are less fortunate: ${ }^{14}$

"If your hand is broken, look at theirs, which is severed. If you have only one eye, look at the blind, who lack both eyes, and offer thanks to God!" ( $p$. 278)

The act of remembrance (dhikr) should be directed towards gratitude and positive thought (husn zann) as stated above.

\section{Detachment (zuhd)}

Muslims believe that there is only one Creator and Eternal being; Allah. Everything else is treated as His creation, transitory being that would eventually depart i.e. life and wealth. Following this, man must learn not to over-attach himself with anything that 'seems to belong' to him in this world, including his own subjective experiences e.g. negative emotions, thoughts and urges. These fleeting experiences are just part of oneself and Said Nursi elaborates some practices to detach oneself from the transitory; ${ }^{14}$

"First...contemplation of death. Thinking that the world is transitory, and they themselves are temporary guests charged with duties, they work for eternal life in this way... Second; through fasting, religious exercises and asceticism, they try to kill the evil-commanding soul and so be saved from its dangers and from the blind emotions." (p. 283)

The reason why God endows men with desires e.g. sexual and hunger, but prohibits its gratification during certain hours, is to create a sense of control and detachment. The same goes to solah where one detaches from his surroundings to be only with God. Detaching from one's emotions does not equate to being stoical, but rather one turns these emotions towards beneficial things, first by acknowledging the emotions but then redirecting one's focus to something more important and everlasting: ${ }^{24}$

"Everyone feels anxiety about the future. A person is intensely anxious about the future, but then sees that he has no guarantee that he will reach the 
future he is so anxious about...So he turns away from the future towards the true future beyond the grave, which is long-lasting and which for the heedless has not been promised." ( $p .49)$

\section{Prayer/Supplication (dua)}

Patients normally have the need to vent their worries or concerns to someone, but sometimes there is none who is available to listen. Alternatively, prayer is a powerful outlet for this. Illness awakens one from heedlessness and triggers the sense of weakness, impotence and poverty, where a prayer delivers its healing. ${ }^{10}$ Said Nursi also asserts in The Twenty Fourth Letter of his Risale- $i$ Nur about inner happiness and comfort one attains through supplication; ${ }^{25}$

"The best, finest, sweetest, most immediate fruit and result of supplication is this, there is someone who listens to his voice, sends a remedy for his ailment, takes pity on him, and whose hand of power reaches everything. He is not alone in this great hostile world; there is an All-Generous One Who looks after him and makes it friendly. Imagining himself in the presence of the One Who can bring about all his needs and repulse all his innumerable enemies; he feels $a$ joy and relief." (p. 350)

\section{Psycho-social support (takaful)}

Proposing an intervention from a spiritual perspective does not stop Said Nursi from highlighting the relationship of psycho-social support and severity of illness. Being mindful of the benefits of caring for the sick, he persuades people to treat the sick with kindness and compassion; ${ }^{14}$

"Pleasures are experienced at the time of illness which arise from the kindness, pity, and compassion of those around, and are most pleasant and agreeable and reduce the pains of illness to nothing" (p. 277)

Said Nursi emphasizes in his writings that compassion is an essential faculty for human beings as for him, Muslims should have compassion in their hearts for everything in the universe and it should be turned into practice.

\section{CONCLUSION}

At a theoretical level, this article has identified the unique spiritual conception of health and illness based on the Risale-i Nur. It has explained the psycho-spiritual therapeutic principles which are derived from the Quran. The possible implications of the 'Message for the Sick' in relieving depressive and anxiety symptoms among general populations or those with physical illnesses, must be further objectively examined. These theoretical suggestions obviously require empirical validation if it was to be offered as a therapy in clinical practice. Presentism bias in this article must also be rightly noted.

\section{CONFLICT OF INTEREST}

None

\section{ACKNOWLEDGEMENT}

None

\section{REFERENCE}

1. Olver JS, Hopwood MJ. Depression and physical illness. Medical Journal of Australia. 2013;199:S9-12.

2. Beck AT, ed. Cognitive therapy of depression. New York; Guilford press, 1979

3. Hamdan A. Cognitive restructuring: An islamic perspective. Journal of Muslim Mental Health. 2008;3:99-116.

4. Beshai S, Clark CM, Dobson KS. Conceptual and pragmatic considerations in the use of cognitive-behavioral therapy with Muslim clients. Cognitive therapy and research. 2013 Feb 1;37(1):197-206.

5. Koenig HG, Pearce MJ, Nelson B, Shaw SF, Robins CJ, Daher NS, Cohen HJ, Berk LS, Bellinger DL, Pargament KI, Rosmarin DH. Religious vs. conventional cognitive behavioral therapy for major depression in persons with chronic medical illness: A pilot randomized trial. The Journal of nervous and mental disease. 2015 Apr 1;203(4):243-51.

6. Rothman A, Coyle A. Toward a framework for Islamic psychology and psychotherapy: an Islamic model of the soul. Journal of religion and health. 2018 Oct 1;57(5):1731-44. 
7. Keshavarzi $\mathrm{H}$, Haque A. Outlining a psychotherapy model for enhancing Muslim mental health within an Islamic context. International Journal for the Psychology of Religion. 2013 Jul 1;23(3):230-49

8. Vahide Ș. Bediuzzaman Said Nursi. Kuala Lumpur: The Other Press, 2011.

9. Besiroglu L, Karaca S, Keskin I. Scrupulosity and obsessive compulsive disorder: The cognitive perspective in Islamic sources. Journal of religion and health. 2014;1:3-12.

10. Tekke M, Watson PJ. Supplication and the Muslim personality: Psychological nature and functions of prayer as interpreted by Said Nursi. Mental Health, Religion \& Culture. 2017;7:143-53.

11. Thomas NS. The Role of Nursi's Risale-i Nur in Psychological Wellbeing. Malaysian Journal of Medicine and Health Sciences. 2019 April 15 (SUPP1):37-44.

12. Conference $\mathrm{IH}$. Constitution of the World Health Organization. 1946. Bulletin of the World Health Organization. 2002;80: 983.

13. Jambroes $M$, Nederland $T$, Kaljouw M, Van Vliet K, Essink-Bot ML, Ruwaard D. Implications of health as 'the ability to adapt and self-manage' for public health policy: a qualitative study. The European Journal of Public Health. 2015;26:412-6.

14. Nursi S. The Flashes. Vahide Ş, translator. Istanbul: Sozler Publication, 2002

15. Nursi S. The Flashes. Vahide S, translator. In: eRisale [online]. Available at: http:// erisale.com/index.jsp? locale=en\#content.en.203.266. Accessed April 92019

16. Nursi S. The Flashes. Vahide Ş, translator. In: eRisale [online]. Available at: http:// erisale.com/index.jsp? locale=en\#content.en.203.272.Accessed April 92019

17. Sayilgan MS.Constructing an Islamic ethics of non-violence: the case of Bediuzzaman Said Nursi [master's thesis]. Edmonton: University of Alberta;2012

18. Basar A. A Lifelong Principle: Positive Action. Proceeding of The Third International Symposium on Bediüzzaman Said Nursi the Reconstruction of Islamic Thought in the
Twentieth Century and Bediuzzaman Said Nursi; 1995 Sept 24-26; Istanbul, Turkey. Istanbul: Sozler; 1995

19. Vahide S. Islam in modern Turkey: an intellectual biography of Bediuzzaman Said Nursi. New York: SUNY Press, 2012

20. Wehr H. Arabic-English Dictionary: The Hans Wehr Dictionary of Modern Written Arabic. Edited by JM Cowan. 4th ed. Wiesbaden, Harrassowitz. 1979.

21. Nursi S. The Words. Vahide Ş, translator. In: eRisale [online]. Available at: http:// erisale.com/index.jsp? locale=en\#content.en.201.281. Accessed April 92019

22. Vahide S. Selection from Nursi's writing in spirituality. In: Abu-Rabi IM, ed. Spiritual Dimensions of Bediuzzaman Said Nursi's RisaleI Nur. New York: SUNY Press, 2008

23. al-Jaza'iry ABJ. Minhaj Al-Muslim (The Way of the Muslim). Riyadh: Dar-us-Salam Publications, 2001

24. Nursi S. The Letters. Vahide Ș, translator. In: eRisale [online]. Available at: http:// erisale.com/index.jsp? locale=en\#content.en.202.49. Accessed April 92019.

25. Nursi S. The Letters. Vahide Ş, translator. In: eRisale [online]. Available at: http:// www.erisale.com/? locale $=$ en\&bookld=202\&pageNo=350\#content. en.202.350. Accessed April 92019. 